\title{
Selective settlement of deep-sea canyon nematodes after resuspension - an experimental approach
}

\author{
Lidia Lins ${ }^{\mathrm{a}, \mathrm{b}, *}$, Ann Vanreusel a , Jelle van Campenhout a , Jeroen Ingels ${ }^{\mathrm{a}, \mathrm{c}}$ \\ a Marine Biology Department, Ghent University, Krijgslaan 281 S8, 9000 Ghent, Belgium

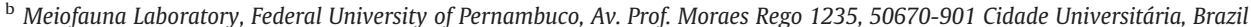 \\ c Plymouth Marine Laboratory, Prospect Place, The Hoe, Plymouth PL1 3DH, United Kingdom
}

\section{A R T I C L E I N F O}

\section{Article history:}

Received 19 July 2012

Received in revised form 18 December 2012

Accepted 21 January 2013

Available online 17 February 2013

\section{Keywords:}

Deep sea

Nematodes

Resuspension

Settlement

\begin{abstract}
A B S T R A C T
Dispersal processes are known to influence dynamics of marine benthic communities. It has been argued that as a result of nematodes being small in size and lacking pelagic larvae, it is unlikely that they are able to disperse actively over wide geographical ranges. Nematode dispersal is therefore assumed to be predominantly driven by water currents entraining resuspended sediments containing nematodes. Three different types of substrates combined with sediment (algae, bacteria, and sulphides) and two different controls (empty and azoic sediment) were offered to a nematode community sinking through the water column in three independent, simultaneously running replicated experiments. Selective settlement of nematodes was observed whilst descending in the water column under ex-situ experimental conditions using samples collected in the Whittard canyon at $812 \mathrm{~m}$ of water depth. Significant differences in nematode community structure between treatments suggest that different nematodes are attracted by different substrates. They may colonise suitable patches selectively when descending in the water column, but whether they are attracted by food or by other attractants, such as pheromones or other chemical signals, is still unclear. High abundances of the chemosynthetic, mouthless nematode Astomonema found in the canyon study area over medium-scale distances $(10-100 \mathrm{~m})$ contribute to the idea that resuspension events enable dispersal of nematodes over larger distances, after which active settlement can occur through chemical attraction.
\end{abstract}

(c) 2013 Elsevier B.V. All rights reserved.

\section{Introduction}

The scale of ecological events that affect organisms has important implications for their population and community dynamics. In order to interpret spatial distribution patterns of organisms, information is needed on their life history strategies, colonisation potential and local adaptation and tolerance to environmental changes (Schratzberger et al., 2008). Recent studies (Gallucci et al., 2008; Ullberg and Olafsson, 2003) have demonstrated that water-column processes that impinge on the seafloor form important disturbance events that stimulate enhanced recruitment and dispersal of marine meiofauna by enabling passive entry of the microscopic organisms into the water column (Palmer, 1988). Subsequently, they may easily be carried over short (metres) to large distances (kilometres) by oceanic currents after which settlement can take place.

Nematodes are the most abundant and diverse taxon within the metazoan meiofauna and display a wide distribution in the deep sea, but little is known about its geographic distribution at species level

\footnotetext{
* Corresponding author at: Krijgslaan 281 S8, Mariene Biologie Gelijkvloers, 9000 Ghent, Belgium. Tel.: + 32 477044667; fax: + 3292648598.

E-mail addresses: lidia.linspereira@ugent.be (L. Lins), ann.vanreusel@ugent.be (A. Vanreusel), jeroen.ingels@ugent.be (J. Ingels).
}

(Zeppilli et al., 2011). Nematodes are considered to disperse easily given their position in the sediment surface layers and their minute size, although adult nematodes are expected to have limited dispersal capabilities and thus a reduced gene flow, making restricted species distribution more likely (Fleeger et al., 1984; Zeppilli et al., 2011). Applying the same logic, species favouring habitats that are regularly affected by intense hydrodynamic conditions, are therefore more likely to be dispersed through sediment resuspension and current flow (Zeppilli et al., 2011).

In the deep sea, storm-induced and spatial heterogeneity can affect the near-bottom flow regime and influence shelf-slope exchanges (Boeckner et al., 2009; Ulses et al., 2008), biogeochemical processes, and organism dispersal (Lambshead et al., 2001; Thistle, 1988; Woodgate and Fahrbach, 1999). Submarine canyons have been recognised as very heterogeneous environments, both in terms of topography and the provision of different habitats for benthic organisms (Tyler et al., 2009) including nematodes (Vanreusel et al., 2010b). They are also characterised by high levels of organic matter accumulation and transport, as well as intense hydrographic regimes and disturbance events (e.g. de Stigter et al., 2007; Tyler et al., 2009). The high organic loads, sedimentary trophic conditions and frequency and intensity of disturbance events (e.g. gravity and turbidity flows) observed in canyons may induce intense resuspension and the 
exchange of colonisers. These processes will further support more complex biological assemblages through the creation of new patches which are suitable for colonisation (Ingels et al., 2011b; McClain and Barry, 2010). Benthic communities are considered to play a central role in these post-disturbance, newly-created benthic habitats (Schratzberger et al., 2004). Moreover, the increase in aerobic respiration as a consequence of accumulation of organic matter $(\mathrm{OM})$ in these habitats, in turn leading to greater levels of reduced products such as sulphides, can lead to shoaling of the Redox-potential discontinuity layers (Kiriakoulakis et al., 2011) and may be linked to the presence of sulphide-dwelling species (Ingels et al., 2011b), in addition to the creation of meso- and micro-patchiness.

Regardless the fact that nematodes lack pelagic larvae in their life cycle (Fenchel, 1978), are poor-swimmers (Jensen, 1981), and possess well-developed adaptations against resuspension (Schratzberger et al., 2004), dislodgment, and passive entrainment along with sediments into the water column as results of resuspension events seem to be an important factor contributing to their ubiquity, and high abundance and diversity (Hagerman and Rieger, 1981; Palmer, 1983, 1988; Palmer and Brandt, 1981; Sherman and Coull, 1980). Contrary to what was expected, nematodes are often encountered in the water column (Boeckner et al., 2009) and are able to extend their presence when resuspended far beyond what was previously predicted when settling velocities and hydrodynamics were considered (Palmer, 1983). When hydrodynamic forces diminish temporarily, then active choice of settlement may play a dominant role in determining spatial structure for some meiofauna taxa, such as copepods (Fleeger et al., 1995; Service and Bell, 1987). Whether this is the case for nematodes in the deep sea has not been investigated until now.

After being transported, the settlement process of nematodes has shown not to be merely of a passive nature (Palmer, 1988), implying that their settlement cannot be described as a process of 'sinking particles'. In an experimental study, Ullberg and Olafsson (2003) have found that some shallow-water nematode genera settled selectively as they descended through the water column in treatments containing algae. The fact that different genera settle selectively is likely caused by the characteristic body shape differences between these genera, but may also be evoked by chemical attraction. This implies that nematodes can actively influence their horizontal movement when descending. Moreover, it was also observed that nematodes are able to form aggregates through species-specific chemical signalling using pheromones (Braendle, 2012; Choe et al., 2012) in a process termed population density-dependent dispersal (Yamada et al., 2010). These pheromones may help the nematode to find a suitable spot to settle, as they regulate also olfactory plasticity and behaviour. Whether they can actively influence their vertical position (e.g. by delaying their descent or active swimming) remains unproven. Also, the question whether deep-sea nematodes are attracted by food or chemical cues, or both, remains without clear answer.

Small-scale distribution of nematodes is assumed to be influenced by microtopography and physical structure of the habitat, by the patchy distribution of food sources, and biogeochemical characteristics as well as by intra- and interspecific processes (Fabiano and Danovaro, 1999; Ingels et al., 2009, 2010, 2011b). Chemical marine signalling studies have emphasised that habitat colonisation occurs through trophic relationships (Zimmer and Butman, 2000) and it has been proven that nematodes can chemically sense an array of compounds (Höckelmann et al., 2004). In the sediment, nematodes may search actively for food patches, although they may feed non-selectively once they find a suitable patch (Höckelmann et al., 2004; Moens et al., 1999a, 1999b).

In the deep sea, food input is dependent on the surface organic matter production provided through photosynthesis (Ramirez-Llodra et al., 2010; Vanreusel et al., 2010a), and is subsequently largely controlled by sedimentation and degradation rates in the water column (Fabiano and Danovaro, 1999). However, ecosystems depending on chemosynthetic energy, such as hydrothermal vents and cold seeps, also play an important role in biomass production (Vanreusel et al., 2010b). Colonisation experiments have shown that nematodes are attracted by treatments enriched with food, especially species which live deeper in the sediment and can withstand hypoxic conditions (Gallucci et al., 2008), although other studies detect no effect of enriched sediments in colonisation processes (Guilini et al., 2011).

This study was conducted with samples from the upper Whittard Canyon, which is located on the Celtic margin, Northeast Atlantic. This canyon receives high loads of OM, and is very likely to experience high rates of degradation of $\mathrm{OM}$ and production of reduced compounds, which, in turn, favours the presence of chemosynthetic nematode species, such as Astomonema southwardorum. This species was described previously from a cold seep in the North Sea sediments, where also a high meiofaunal and nematode diversity was exhibited (Austen et al., 1993; Ingels et al., 2011b; Tchesunov et al., 2012). Our main aim was to assess by means of settling experiments if nematode communities (and more specific, the chemosynthetic nematode $A$. southwardorum) from the Whittard canyon are able to actively select specific substrates (including a sulphidic substrate) when descending to the seafloor after a simulated resuspension event.

\section{Material and methods}

\subsection{Sampling}

The samples used in the experiment were collected from the upper Whittard Canyon (Belgica cruise 2010/17b, 19-28 june/2010). This canyon extends from the shelf break of the Celtic Shelf south of Goban Spur to the abyssal plain. It contains deeply incised branches with side walls occasionally larger than $500 \mathrm{~m}$ (Van Rooij et al., 2010) and is influenced by strong tidal currents (Holt and Thorpe, 1997). This canyon acts as a trap for organic material by semi-diurnal tides and seems to be locally enriched compared to the open slope (Goban Spur) (Cunningham et al., 2005). A multicorer (MUC) was used to collect virtually undisturbed sediments $\left(78.54 \mathrm{~cm}^{2}\right)$ from a depth of $812 \mathrm{~m}\left(48^{\circ} 46.5009^{\prime} \mathrm{N} ; 10^{\circ} 38.4987^{\prime} \mathrm{W}\right)$ and the first $5 \mathrm{~cm}$ from one core was used in the experiment, which was conducted on board in a temperature-regulated laboratory.

The meiofauna was separated from the macrofauna after retrieval by sieving through a $1000 \mu \mathrm{m}$ mesh and on a $32 \mu \mathrm{m}$ mesh. The sample from the $32 \mu \mathrm{m}$ mesh was homogenised and separated in three same-volume subsamples to use in each of the three replicated experiments (the sample was placed into a jug filled with filtered ( $32 \mu \mathrm{m}$ ) seawater and stirred to achieve a homogenous suspension. This method is considered efficient for splitting samples to use for non-quantitative purposes.

\subsection{Experiment}

Three plastic vessels were used as the experimental settling chambers $(31 \mathrm{~cm}$ bottom internal diameter, $150 \mathrm{~L}$ ). The total area of the vessel bottom was approximately $3017 \mathrm{~cm}^{2}$. The vessels were filled with filtered $(32 \mu \mathrm{m})$ sea water and the settling distance from the surface was approximately $50 \mathrm{~cm}$ (Fig. 1).

At the bottom of each vessel 5 Petri dishes were placed containing different substrates: one with algae and azoic sediment (Sd), one with bacteria and azoic sediment ( $\mathrm{Sb})$, one with a sulphidic medium ( $\mathrm{Su}$ ) and two controls (one with (C) and one without (Cs) azoic sediment). The algae treatment contained a fine layer of azoic sediment and $1.6 \mathrm{~g}$ (dry weight) of Tetraselmis suecica, a dark green freeze-dried microalgae with $10-15 \mu \mathrm{m}$ particle size after resuspension, $2-5 \times 10^{9}$ cell density per gramme dry weight and percentages of carbon and nitrogen of $39.3 \%$ and $4.85 \%$, respectively. The bacteria treatment contained a fine layer of azoic sediment together with $20 \mathrm{~mL}$ unidentified strains of bacteria solution $(0.001537 \mathrm{~g} / 1.5 \mathrm{ml}$ dry weight $)$ from tidal flat samples cultured in 'rich broth' $(2 \times 2 \mathrm{~L})$. 'Rich broth' 

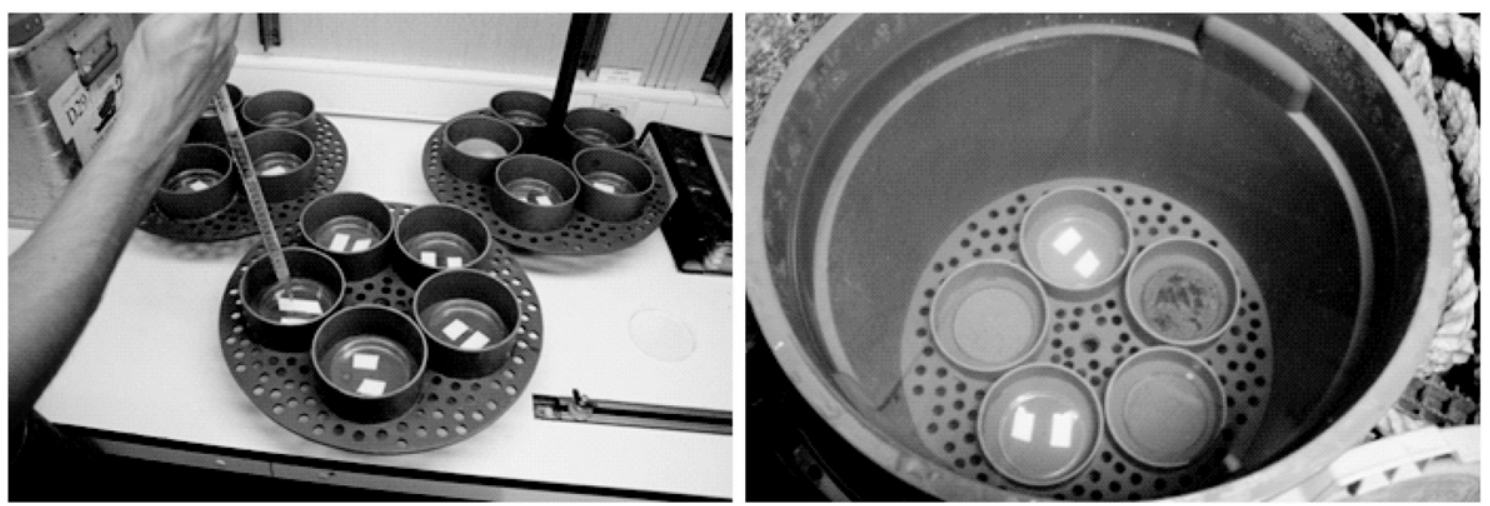

Fig. 1. Design of the experiment.

consisted of $0.4 \mathrm{~g} / \mathrm{L}$ bactobeef and $0.66 \mathrm{~g} / \mathrm{L}$ bactopeptone; a small aliquot of bacteria was added and left to grow for $36 \mathrm{~h}$ on a shaker (120 rpm). Bacteria were subsequently centrifuged and washed several times (5000 rpm, $15 \mathrm{~min}$ ) to concentrate the microbial solution. The sulphidic medium consisted of $50 \mathrm{~mL}$ of sulphidic agar. The sulphidic medium was made with 1 L Artificial Sea Water (following Moens and Vincx, 1998), 0.8\% agar (8 g bactoagar/L), $2.5 \mathrm{~g} / \mathrm{L}$ Natriumthiosulfate $\left(\mathrm{Na}_{2} \mathrm{~S}_{2} \mathrm{O}_{3}\right), 2.5 \mathrm{~g} / \mathrm{L}$ Natriumsulfide $\left(\mathrm{Na}_{2} \mathrm{~S}\right)$. A Petri dish containing the semi-solidified sulphidic medium was chosen because of the occurrence of sulphidic-dwelling nematodes in the Whittard canyon, such as the genus Astomonema (Ingels et al., 2011b; Tchesunov et al., 2012). The control dishes were filled with a fine layer of azoic sediment or kept empty. The azoic sediment used as substrate in the experiments was collected in the Whittard canyon during an earlier campaign with the R/V Belgica in 2006 (Ingels et al., 2006), and burned overnight at $500{ }^{\circ} \mathrm{C}$ to remove all organic material and homogenised before experimental use. The Petri dishes were filled up to the same level (except for the $C$ treatment) and placed equidistantly from each other on a perforated bottom in the plastic vessel (Fig. 1). Migration of the nematodes to other treatments after settlement had taken place, is highly unlikely. The fact that the Petri-dishes secluded the treatments from each other meant that nematode migration through sediments was not possible. In a similar triplicated experiment, which was run simultaneously with the here presented experiment (unpublished data), nematodes were placed in a Petri dish surrounded by Petri dishes containing the same treatments as in the here presented experiment; there was no exchange of nematodes observed, hence implying that nematodes were not being resuspended in the water-column post-settlement and redistributed among the treatments following ship movement and/or other disturbances.

Prior to the experiment, the Petri dishes were placed in a perforated plastic tray to allow the water to run off upon retrieval and the vessels were filled with filtered sea water and left to acclimatise at in-situ temperature (8-9 ${ }^{\circ} \mathrm{C}$, according to CTD data at the sampling location). At the start of the experiment, the nematodes which were retained in the $32 \mu \mathrm{m}$ sieve were transferred to a plastic vessel together with filtered sea water and then were poured into the experimental vessel and equally spread over its surface water by a gentle stirring action. The vessels were left for $24 \mathrm{~h}$ after which the water was carefully syphoned off. The Petri dishes were then collected and the content of each Petri dish was immediately fixed with Borax-buffered $4 \%$ formalin (diluted with $32 \mu \mathrm{m}$ filtered sea water). To avoid biassed results or nematode concentration at particular sides of the experimental vessels due to the ship motion the Petri dishes were positioned randomly in each replicate vessel and thus subjected to the same motion effects.

\subsection{Meiofauna and nematode analyses}

Upon return to the lab at the Marine Biology research group UGent, the meiofauna samples were washed over a $1000 \mu \mathrm{m}$ mesh size to remove larger particles contained in the inorganic sediment and sieved on a $32 \mu \mathrm{m}$ mesh to retain the meiofauna and remove smaller particles and diatoms and bacteria. The meiofauna was elutriated and centrifugated three times $(\mathrm{G}$-force $=6056.12 \mathrm{~g}, \mathrm{RPM}=5421$ ) with colloidal silicagel LUDOX HS40 Dupont (specific gravity 1.19) as a flotation medium (Heip et al., 1985). This method allows the separation of the meiofauna from the sediment following the density gradient, where the first floats and the second remain on the bottom. After the centrifugation, the meiofauna was stained with Rose Bengal ( to facilitate their identification) and counted under a stereomicroscope (50 $\times$ magnification). The different meiofauna groups were identified at higher taxonomic level following Higgins and Thiel (1988). All nematodes were picked out from the samples. They were transferred gradually to glycerine (De Grisse, 1969) and mounted on glass slides. All nematodes were identified down to genus level following pictorial keys (Warwick et al., 1998) and the NeMys Database (Deprez, 2005). They were grouped in trophic levels according to Wieser (1953), complementing the $2 \mathrm{~B}$ group (predators) with the notion of 'scavengers' (Jensen, 1987) and adding one additional feeding type (3) created to accommodate the presence of the mouthless genus Astomonema (following Ingels et al., 2011b) which cannot be grouped in any of Wieser's feeding groups. Their life stage (juvenile/adult) and gender (male/female) were determined. The length (excluding filiform tail tips) and the maximum body width were measured for all nematodes with the compound microscope Leica DMR and Leica LAS 3.3 imaging software. Biomass was then calculated per genus through the volumetric method according to Andrassy's formula $G=a^{2} \times b / 1.6 \times 10^{6}$, with $\mathrm{G}=$ wet weight in $\mu \mathrm{g}$, $\mathrm{a}=$ maximum body diameter $(\mu \mathrm{m})$ and $\mathrm{L}=$ total length $(\mu \mathrm{m})$ (Andrássy, 1956).

\subsection{Data analysis}

Nematode assemblages were analysed by means of non-parametric multivariate permutational ANOVA (PERMANOVA; Anderson, 2005) to assess differences between the different sample treatments: control (C), control with azoic sediment (Cs), sulphide (Su), sediment with bacteria $(\mathrm{Sb})$ and sediment with diatom (Sd), and between the different replicates (the latter to assess replicate effects). Therefore, a two-way PERMANOVA randomised block design (treatment: Fixed; replicate: random, nested in treatment) with five fixed treatment levels (Factor treatment), 9 contrasts $(\mathrm{Cs} \times \mathrm{C}$; $\mathrm{Cs}, \mathrm{C} \times \mathrm{Sd}, \mathrm{Sb}, \mathrm{Su}$; $\mathrm{Sb}, \mathrm{Su} \times \mathrm{Sd}$; $\mathrm{Sb}, \mathrm{Su} \times \mathrm{Cs}$, $\mathrm{C} ; \mathrm{Cs} \times \mathrm{Sb}, \mathrm{Sd}, \mathrm{Su} ; \mathrm{Sb} \times \mathrm{Sd}$; $\mathrm{Sd} \times \mathrm{Su} ; \mathrm{Sb} \times \mathrm{Su} ; \mathrm{C} \times \mathrm{Sb}, \mathrm{Sd}, \mathrm{Su}$ ), and three random replicates (Factor replicate) was performed. PERMANOVA tests were favoured over traditional ANOVA procedures, because ANOVA assumes normal distributions and uses Euclidean distance as a resemblance measure, whilst PERMANOVA works with any distance measure that is appropriate for the data (in this case Bray Curtis). Contrasts were used to compare mainly differences between the controls and the treatments (to observe "food" effect) or between the sulphide treatment and the other groups (to observe if Astomonema individuals had a 
preference for this medium). The PERMANOVA tests were performed on the multivariate genera relative abundance, total biomass and total nematode length data, and the multivariate feeding-type and genderlife-stage relative abundances. Genera abundance data was standardised and dispersion weighting was applied to stabilise the quality of information from each genus that is input to the multivariate routine (Clarke et al., 2006). In this case, downweighting is desirable because of the 'erratic' abundance of the genus Astomonema in different replicates of a treatment group and also due to the aggregation pattern commonly found in nematodes, which adds noise rather than "signal" to the data and should be removed (Clarke et al., 2006). In all cases, data was standardised and the Bray-Curtis similarity index was used to calculate resemblance, to take into account relative abundance differences between genera (Bray and Curtis, 1957). When the number of unique permutations was lower than one hundred, the Monte Carlo p values were used (Anderson and Robinson, 2003). Principal Coordinates Ordination (PCO) plots were used to visualise the resemblance of nematode genera assemblages from different experimental treatments in multivariate space. PCO was preferred over non-metric Multi-Dimensional Scaling (nMDS), because it preserves the original dissimilarity distances between samples in a multivariate Bray-Curtis space and provides a better representation of the distance between samples within a treatment when distances between different treatment groups of samples are greater. nMDS uses rank order information rather than actual dissimilarity distances (Anderson et al., 2008).

Diversity indices of Hill $\left(\mathrm{N}_{1}, \mathrm{~N}_{2}\right.$ and $\left.\mathrm{N}_{\infty}\right)$, Shannon-Wiener diversity index and Pielou's evenness (Heip et al., 1998) index were calculated for the samples to obtain a quantitative estimate of the biological variability in terms of diversity and evenness within the communities (Heip et al., 1998; Hill, 1973). A two-factor randomised block-design PERMANOVA (treatment: Fixed; replicate: random, nested in treatment) using the multivariate diversity data was performed to assess differences of diversity and evenness indices between treatments and replicates.

\section{Results}

\subsection{Community structure in experimental samples}

A total of 101 nematode genera were identified. Combining all treatments, the five most abundant genera accounted for $36 \%$ of the total community (Astomonema 12\%, Halalaimus 9\%, Daptonema 6\%, Amphimonhystrella 5\% and Acantholaimus 4\%). Leptolaimus, Molgolaimus, Sabatieria and Actinonema each accounted for $3 \%$ of the total (Table 1). The other genera were less abundant $(<2 \%)$.

The two-way PERMANOVA based on nematode genera composition showed significant differences between treatments $(p<0.02)$ but not between the contrasts (Table 2). A PCO plot showed a clear separation of the three food source treatments, but the controls were dispersed among the other treatments. The $\mathrm{X}$ axis explained $19.1 \%$ of total variation, followed by $14.7 \%$ for the $Y$ axis (Fig. $2 \mathrm{~A}$ ). The abundant genera which had Spearman correlations $(>0.8)$ with the PCO axes were Sabatieria, Amphimonhystrella and Astomonema. Sabatieria and Amphimonhystrella were correlated with the Sb treatment (bacteria) and Astomonema with the Su treatment (sulphides).

\subsection{Nematode biomass and nematode length}

The two-way PERMANOVA for the total nematode length showed no significant results $(\mathrm{p}<0.56)$, as well as the total biomass per genus $(p<0.22)$ (Fig. 2B). There were no significant differences observed for the contrasts.

\subsection{Trophic structure and gender/life stage}

Regarding the trophic diversity and gender/life stage (male, female and juveniles) patterns no significant differences were observed
Table 1

Average $(n=3)$ percentage contribution to total nematode abundance in each experimental sample $(\mathrm{Cs}=$ control with sediment; $\mathrm{C}=$ control without sediment; $\mathrm{Sb}=$ bacteria treatment; $\mathrm{Sd}=$ diatom treatment; $\mathrm{Su}=$ sulphide treatment).

\begin{tabular}{llrrrr}
\hline Genera & CS & \multicolumn{1}{c}{$\mathrm{C}$} & \multicolumn{1}{l}{ Sb } & \multicolumn{1}{c}{ Sd } & \multicolumn{1}{c}{ Su } \\
\hline Acantholaimus & $7.5 \pm 2.1$ & $3.7 \pm 3.1$ & $5.6 \pm 2.7$ & $5.6 \pm 1.9$ & $4.9 \pm 0.5$ \\
Actinonema & $4.7 \pm 2.9$ & $3.3 \pm 4.9$ & $4.0 \pm 0.9$ & $4.0 \pm 0.7$ & $3.8 \pm 2.0$ \\
Amphimonhystrella & $4.0 \pm 4.4$ & $5.7 \pm 1.5$ & $4.8 \pm 1.2$ & $4.8 \pm 1.0$ & $5.1 \pm 1.7$ \\
Astomonema & $9.0 \pm 1.0$ & $11.0 \pm 4.0$ & $10.0 \pm 1.4$ & $10.0 \pm 1.0$ & $10.3 \pm 1.6$ \\
Daptonema & $4.0 \pm 2.0$ & $7.7 \pm 6.7$ & $5.8 \pm 2.6$ & $5.8 \pm 1.8$ & $6.4 \pm 2.5$ \\
Halalaimus & $4.3 \pm 2.3$ & $10.0 \pm 10.6$ & $7.2 \pm 4.0$ & $7.2 \pm 2.8$ & $8.1 \pm 4.4$ \\
Leptolaimus & $4.0 \pm 2.0$ & $1.7 \pm 1.2$ & $2.8 \pm 1.6$ & $2.8 \pm 1.2$ & $2.4 \pm 0.4$ \\
Molgolaimus & $1.0 \pm 1.0$ & $5.7 \pm 4.5$ & $3.3 \pm 3.3$ & $3.3 \pm 2.3$ & $4.1 \pm 1.8$ \\
Sabatieria & $2.0 \pm 1.7$ & $2.0 \pm 2.0$ & $2.0 \pm 0.0$ & $2.0 \pm 0.0$ & $2.0 \pm 1.1$ \\
\hline
\end{tabular}

between treatments for the two-way PERMANOVA ( $p<0.47$ and $\mathrm{p}<0.52$, respectively). The PCO plot (not shown) shows no difference among the treatments, with all of them clustered together. There was a dominance of selective (1A) and non-selective deposit feeders (1B) (Table 3).

\section{Discussion}

\subsection{Community patterns and selective settlement/colonisation}

The reasons why nematodes are successful in colonising different environments are very poorly understood. It is known that some species of nematodes are considered to have a wide distribution as a result of trans-oceanic dispersal (Decraemer et al., 2001; Zeppilli et al., 2011) and the cosmopolitan distribution of a range of meiofauna taxa is probably the result of a variety of dispersal mechanisms (Zeppilli et al., 2011). A possible important contributor to the dispersal processes may be the capacity of organisms to choose a suitable spot to colonise after resuspension and their transport with currents. The significant nematode community differences between treatments in the present study suggest that, once nematodes have entered the water column and the currents/disturbance subside, they seem able to settle selectively, depending on the patches and food resources available. Some studies have already shown that nematodes can actively colonise empty patches by moving through the sediment, thereby determining to an extent the small-scale heterogeneity of the environment (Lee et al., 1977). Such migration through the sediment is assumed to occur through the nematodes' ability to both chemically sense their biochemical environment and food resources (Choe et al., 2012; Höckelmann et al., 2004). Chemical sensing is widely acknowledged to be present in nematodes, both for parasitical as for free-living

Table 2

Results from the two-way blocked design PERMANOVA analysis for differences in treatments and contrasts from the experimental samples based on community structure noted in relative abundances of genera. ( $\mathrm{df}=$ degrees of freedom; $\mathrm{SS}=$ sum of squares; $\mathrm{MS}=$ mean square; $\mathrm{P}($ perm $)=$ permutation values; Unique perms $=$ unique permutations; $\mathrm{P}(\mathrm{MC})=$ Monte Carlo permutation values). Significant results $(\mathrm{p}<0.05)$ are denoted in bold italics ( $\mathrm{Cs}=$ control with sediment; $\mathrm{C}=$ control without sediment; $\mathrm{Sb}=$ bacteria treatment; $\mathrm{Sd}=$ diatom treatment; $\mathrm{Su}=$ sulphide treatment).

\begin{tabular}{lrrllll}
\hline Source & df & SS & MS & Pseudo-F & P(perm) & P(MC) \\
\hline Treatment & 4 & 6520.1 & 1630 & 1.34 & $\mathbf{0 . 0 2 1 8}$ & \\
Cs $\times$ C & 1 & 2292.8 & 2292.8 & 16.025 & 0.3053 & 10 \\
Cs,c $\times$ sd,sb,su & 1 & 1002.7 & 1002.7 & 0.82079 & 0.8513 & 20 \\
Sb,su $\times$ sd & 1 & 1850.3 & 1850.3 & 17.103 & 0.0519 & 20 \\
Sb,su $\times$ cs,c & 1 & 1247.5 & 1247.5 & 1.001 & 0.5051 & 10 \\
Cs $\times$ sb,sd,su & 1 & 1718.7 & 1718.7 & 14.722 & 0.1559 & 20 \\
Sb $\times$ sd & 1 & 1796.9 & 1796.9 & 16.546 & 0.1001 & 10 \\
Sd $\times$ su & 1 & 1665.7 & 1665.7 & 15.358 & 0.0982 & 10 \\
Sb $\times$ su & 1 & 1374.3 & 1374.3 & 13.086 & 0.2046 & 10 \\
C $\times$ sb,sd,su & 1 & 1254.4 & 1254.4 & 0.99002 & 0.4521 & 20 \\
Replicate(treatment) & 10 & 12,165 & 1216.5 & No test & & \\
Total & 14 & 18,685 & & & & \\
\hline
\end{tabular}



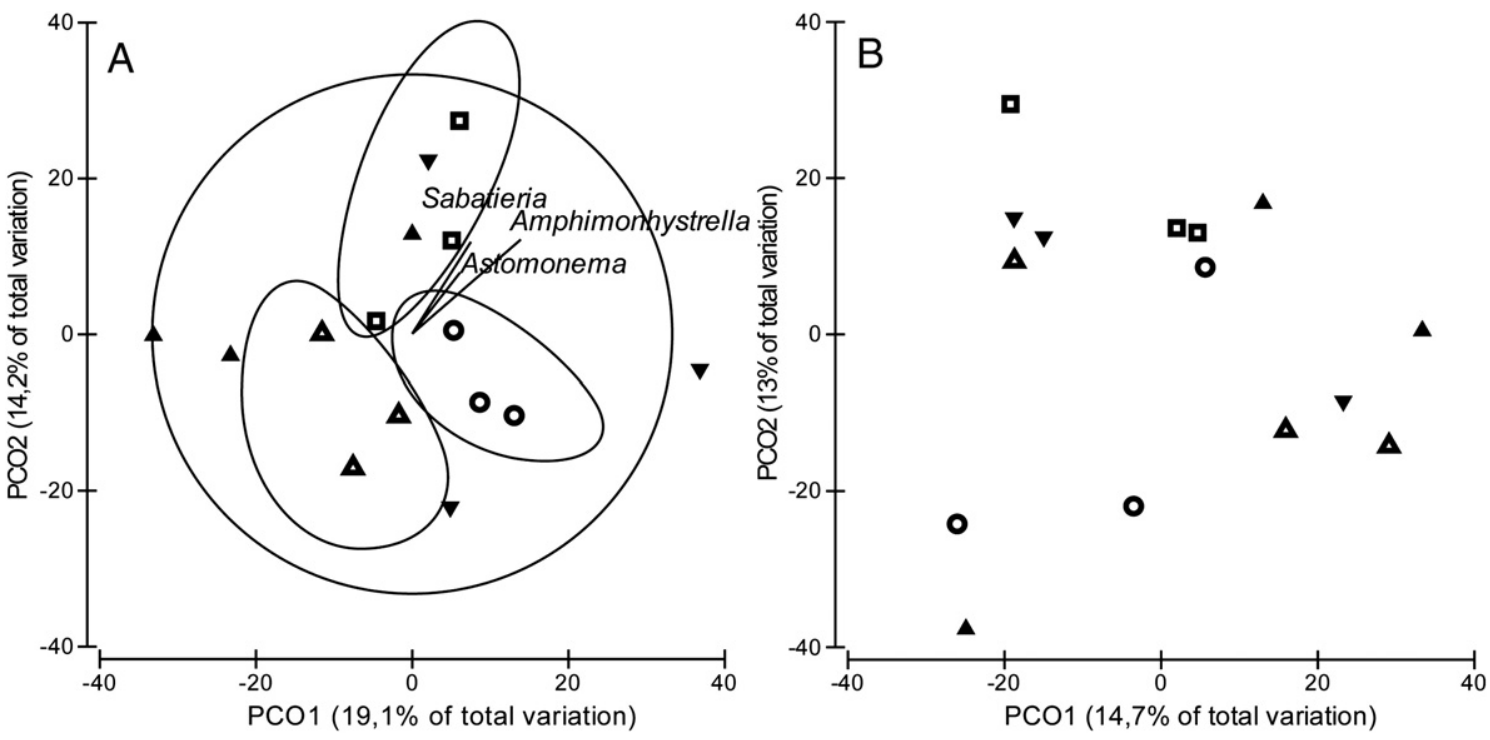

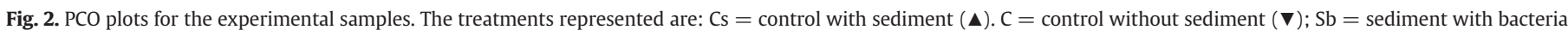

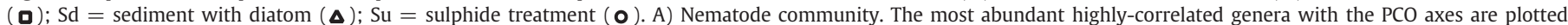
(Amphimonhystrella, Sabatieria and Astomonema); B) Nematode biomass.

nematodes, a capacity that has developed and diversified throughout the evolution of the different nematode lineages (Braendle, 2012). Due to this chemical sensing ability, it is highly likely that nematodes may actively choose their potential settlement site (Höckelmann et al., 2004) after being passively resuspended to the water-column, by directing themselves towards the source they are attracted to.

Moens et al. (1999a) proposed that nematodes can actively choose their food source but feed rather non-selectively once they find a suitable patch. In this context, the optimal foraging theory would imply strategic localisation and migration to a suitable food patch, followed by exploiting the variety of available nutritious food resources present in the new patch instead of investing energy in selecting and exploiting the food sources available in the immediate vicinity which may be of lesser quality. Such a strategy may be especially rewarding for free-living nematodes which are descending in the water column following resuspension, because even though their motility in water is considered limited, swimming movements towards a suitable source is likely to be energetically less demanding than active movements through the more rigid sediment particle matrix over the same distances; and likely much more rewarding. Another argument supporting the possible importance of 'migration before exploitation' is the limitation of food resources; in food-poor environments such as the deep sea, migration towards suitable patches must be favoured in order to fulfil energetic and nutritional requirements. The differences between treatments found in our experiment imply that different species are attracted by different substrates, supported by the correlation of Astomonema with the sulphide direction in the PCO plot. In this particular context the sulphide can be seen as an indirect food source, i.e. it would serve the endosymbiotic bacteria in performing chemosynthesis. Astomonema is a deep-dwelling nematode which lives in

\section{Table 3}

Trophic group distribution for each treatment (average \pm standard deviation). Cs $=$ control with sediment; $\mathrm{C}=$ control without sediment; $\mathrm{Sb}=$ bacteria treatment; $\mathrm{Sd}=$ diatom treatment; $\mathrm{Su}=$ sulphide treatment.

\begin{tabular}{lccccc}
\hline $\begin{array}{l}\text { Trophic } \\
\text { group }\end{array}$ & Cs & C & SB & SD & Su \\
\hline 1a & $19.7 \pm 6.1$ & $26.3 \pm 17.1$ & $21.0 \pm 5.6$ & $23.3 \pm 14.0$ & $23.7 \pm 5.5$ \\
1b & $20.0 \pm 9.5$ & $26.7 \pm 14.4$ & $25.7 \pm 9.6$ & $15.7 \pm 7.6$ & $23.0 \pm 4.0$ \\
2a & $19.7 \pm 12.3$ & $18.0 \pm 13.1$ & $12.3 \pm 5.8$ & $15.7 \pm 9.1$ & $15.3 \pm 4.5$ \\
2b & $5.7 \pm 3.2$ & $4.0 \pm 0.0$ & $6.3 \pm 5.5$ & $5.0 \pm 3.0$ & $7.3 \pm 3.8$ \\
3 & $9.0 \pm 1.0$ & $11.0 \pm 4.0$ & $7.7 \pm 0.6$ & $5.7 \pm 0.6$ & $17.7 \pm 14.6$ \\
\hline
\end{tabular}

anoxic/hypoxic environments and possible advantages of choosing a specific suitable patch - besides food availability - could be to find mates and copulate, probably as a result of density-dependent migration (Palmer, 1988). In addition, nematode intra- and inter-specific interactions may be influenced by the presence of pheromones (Choe et al., 2012; Jensen, 1982). Although a chemical attraction over medium and large distances (metres to kilometres) would be improbable, pheromones could act as an attractant in the settling process of nematodes. In this experiment, the offered Petri-dish substrates did not contain any nematodes, but chemical signalling by the first settlers cannot be excluded as an aid to selective settlement (Choe et al., 2012). Patterns in chemotaxis are already clear for some groups, such as the annelid Protodrilus rubropharyngeus, which is positively attracted to bacteria (Gray, 1967) and blue crabs (Callinectes sapidus), which employ their chemical senses to forage, but for the meiofauna this is still unclear (Zimmer and Butman, 2000). More recent evidence for nematodes, however, suggests that nematode-specific pheromone attraction may be a powerful mediator for migration processes.

Hitherto, some studies have shown that the relationship between nematode and food sources can be species-specific (Höckelmann et al., 2004; Jensen, 1987; Moens and Vincx, 1997; Moens et al., 1999a, 1999b), whilst others report uncertainty on whether nematodes are really limited by specific food- or energy-source requirements (Giere, 2009). Benthic ecosystems in the deep sea are generally sustained by micro-algal detritus associated with bacterioplankton which settles to the sea floor (Gooday, 2002). Nevertheless, experiments conducted in the deep sea or with deep-sea samples in the laboratory are equivocal as to whether nematodes feed predominantly on bacteria (Ingels et al., 2010, 2011a), on microalgae (Gallucci et al., 2008) or either (Guilini et al., 2011). Apart from diatoms and bacteria as a food source, labile OM liberated from the particulate pool by extracellular enzyme activity, viral infection and metazoan feeding processes is considered as material readily available for organisms and could be an important factor regulating meiofauna and specifically nematodes communities (Danovaro et al., 1995; Gontikaki et al., 2011; Neira et al., 2001; Rowe and Deming, 2011). Which deep-sea free-living nematodes are attracted to what types of food, however, remains to be elucidated, as well as the specific mechanisms behind the selection processes.

Total nematode length and biomass did not differ significantly between treatments, and hence selective settlement does not occur on the level of nematode length or biomass. This contradicts previous 
studies, which stated that only the smallest nematodes are able to swim in the water due to their sinusoidal movement (Ullberg and Olafsson, 2003) or that only the big nematodes could swim faster (Gallucci et al., 2008). Our results suggest that the choice of a habitat could be influenced just by the nematodes' ability to distinguish the chemical attractant and not by their size. Due to the lack of planktonic larvae or juvenile stages in nematodes, the active and passive transport of both juveniles and adults are very important to the performance of the population (Commito and Tita, 2002). Although different patterns in erosion (removal of nematodes from the sediments) have been observed for different trophic groups, the lack of differences in settlement following trophic structure differences in our study suggests that a higher erosion rate is not related to settlement efficiency (Commito and Tita, 2002).

It is very likely that the bottom currents in the Whittard canyon are the most important factor influencing passive transport of nematodes, as once suspended they can be transported at rates close to the water velocity (Ullberg and Olafsson, 2003). Studies have already shown that meiofauna individuals can rapidly colonise defaunated areas that are metres away from each other, which is unlikely through active migration through the sediments (Palmer, 1988). Our results suggest that, once the strong currents or sediment flows that have entrained the nematodes have subsided, and the nematodes are descending in the water column, that they are able to direct themselves to suitable patches to fulfil their energetic requirements.

\subsection{Astomonema's capacity to choose sulphidic patches and notes on its distribution}

The symbiosis between $A$. southwardorum species and their endosymbiothic bacteria has been established (Austen et al., 1993; Tchesunov et al., 2012), and has been observed in other Astomonema species (Musat et al., 2007; Ott et al., 2004). These nematodes depend on the energy available through their endosymbionts which thrive on sulphides or methane available in the sediments. The ability to migrate actively or settle selectively in patches of sediments that contain high sulphide levels is likely imperative to the survival of the species and the persistence of its populations.

Nematodes are not mobile enough to explain medium-scale (10$100 \mathrm{~m}$ ) heterogeneity by active dispersal through the sediments, but they can be responsible for small-scale patterns, such as vertical distributions in the sediment or horizontal movement on a microscale (Gallucci et al., 2008; Heip et al., 1985). Astomonema's bacterial endosymbionts require sulphides from deeper/anoxic layers where these sulphides are available, but also oxygen from the superficial or more oxygenated layers. For this reason, Astomonema nematodes need to be able to cover the distance between these different sediment layers and hence migrate vertically and/or horizontally, but on a limited spatial microscale. Their slender body, although not enabling them to migrate over large distances, proves to be ideal for covering distances between deeper and superficial sediment layers. However, the same species of Astomonema was found in high abundances $600 \mathrm{~m}$ further away from our sampling location (Ingels, pers. Comm.) and in the Gollum Channels (about $200 \mathrm{~km}$ north of the Whittard Canyon) (Ingels et al., 2011a), and this species was originally described from seep pockmarks in the North Sea, off the east coast of Scotland (Austen et al., 1993). In this case, passive dispersal(s) during water column processes followed by settlement as 'particles' is the likely explanation for their currently observed distribution. Such dispersal is likely enhanced by shelf-slope exchange processes at the continental margin, which are particularly active at the Irish Margin (Cunningham et al., 2005). Our experimental results, based on the spatial and temporal scales studied, might indicate that Astomonema individuals likely choose where they settle after resuspension whenever there is an environment rich in sulphides to sustain their energetic requirements close by (over a distance of centimetres to metres). The high hydrodynamic activity in the Whittard canyon, together with the possibly anoxic environment and hence availability of sulphides in deeper layers of the sediment (Ingels et al., 2011b) favours Astomonema individuals to disperse, settle and establish patchy populations in this environment. The dominance of Astomonema was also observed in the background samples (unpublished results) of the study location and in samples collected at the same location in 2006, where they represented more than $10 \%$ of the total community (Ingels et al., 2006, 2011b).

Our results bear important implications for the dispersal of deepsea nematodes and their resulting distribution patterns. The prevalence of $A$. southwardorum in the sulphide samples of our experiment and their recovery from non-seep sediments in the Whittard Canyon is particularly relevant in the context of dispersal of seep organisms. If organisms that are usually associated with seep (or other chemosynthetic) environments are able to thrive in high-sulphide spots in non-seep environments, then this sheds new light on the dispersal of seep organisms. Their ability to reach far-away seep habitats may be mediated by medium to large distance passive transport and small scale active settlement, using suitable stepping stones along the way. This seems to be the case at least for A. southwardorum, and perhaps other chemosynthetic nematodes.

\section{Conclusions}

Our results suggest that some nematode taxa can actively choose between different food sources when settling after resuspension into the water-column. Correlation results suggest that the chemosynthetic nematode Astomonema can actively choose for sulphidic substrates when descending through the water column close to the sea floor. This may have implications for our understanding of dispersal of chemosynthetic nematodes in general. Nevertheless, whether nematodes are attracted by food or by other chemical signals (e.g. attractants released by the first settlers) is still not clear.

\section{Acknowledgements}

We would like to thank Dirk van Gansbeke and Bart Beuselink for the biogeochemical processing. This work was supported by VLIR-UOS and performed in the framework of the European Commission's Seventh Framework Programme HERMIONE project (http://www.euhermione.net, grant agreement number 2263541). [RH]

\section{References}

Anderson, M., 2005. PERMANOVA: Permutational Multivariate Analysis of Variance. Department of Statistics, Auckland.

Anderson, M.J., Robinson, J., 2003. Generalized discriminant analysis based on distances. Aust. N. Z. J. Stat. 45, 301-318.

Anderson, M.J., Gorley, R.N., Clarke, K.R., 2008. PERMANOVA+ for PRIMER: Guide to Software and Statistical Methods. PRIMER-E, Plymouth.

Andrássy, I., 1956. The determination of volume and weight of nematodes. Acta Zool. 2, 15.

Austen, M.C., Warwick, R.M., Ryan, K.P., 1993. Astomonema-southwardorum sp-nov, a gutless nematode dominant in a methane seep area in the north-sea. J. Mar. Biol. Assoc. U. K. 73, 627-634.

Boeckner, M.J., Sharma, J., Proctor, H.C., 2009. Revisiting the meiofauna paradox: dispersal and colonization of nematodes and other meiofaunal organisms in lowand high-energy environments. Hydrobiologia 624, 91-106.

Braendle, C., 2012. Pheromones: evolving language of chemical communication in nematodes. Curr. Biol. 22, R294-R296.

Bray, J.R., Curtis, J.T., 1957. An ordination of the upland forest communities of Southern Wisconsin. Ecol. Monogr. 27, 325-349.

Choe, A., von Reuss, S.H., Kogan, D., Gasser, R.B., Platzer, E.G., Schroeder, F.C., Sternberg, P., 2012. Ascaroside signaling is widely conserved among nematodes. Curr. Biol. 22, $772-780$.

Clarke, K.R., Chapman, M.G., Somerfield, P.J., Needham, H.R., 2006. Dispersion-based weighting of species counts in assemblage analyses. Mar. Ecol. Prog. Ser. 320, 11-27.

Commito, J.A., Tita, G., 2002. Differential dispersal rates in an intertidal meiofauna assemblage. J. Exp. Mar. Biol. Ecol. 268, 237-256.

Cunningham, M.J., Hodgson, S., Masson, D.G., Parson, L.M., 2005. An evaluation of along- and down-slope sediment transport processes between Goban Spur and Brenot Spur on the Celtic Margin of the Bay of Biscay. Sediment. Geol. 179, 99-116. 
Danovaro, R., Fabiano, M., Albertelli, G., Dellacroce, N., 1995. Vertical-distribution of meiobenthos in bathyal sediments of the eastern Mediterranean-sea relationship with labile organic-matter and bacterial biomasses. Mar. Ecol.-P.S.Z.N. I $16,103-116$.

De Grisse, A., 1969. Redescription ou modification de quelques techniques utilisés dans l'étude des nématodes phytoparasitaires. Meded. Rijksfak. LandbWet. Gent 34, 251-369.

de Stigter, H.C., Boer, W., Mendes, P., Jesus, C.C., Thomsen, L., van den Bergh, G.D., van Weering, T.C.E., 2007. Recent sediment transport and deposition in the Nazare Canyon, Portuguese continental margin. Mar. Geol. 246, 144-164.

Decraemer, W., Gourbault, N., Helléouet, M.N., 2001. Cosmopolitanism among nematodes: examples from epsilonematidae. Vie Milieu 51, 11-19.

Deprez, T., 2005. Nemys. World Wide Web electronic publication. www.nemys.ugent. be.

Fabiano, M., Danovaro, R., 1999. Meiofauna distribution and mesoscale variability in two sites of the Ross Sea (Antarctica) with contrasting food supply. Polar Biol. $22,115-123$.

Fenchel, T.M., 1978. Ecology of microbenthos and meiobenthos. Annu. Rev. Ecol. Syst. 9, 99-121.

Fleeger, J.W., Chandler, G.T., Fitzhugh, G.R., Phillips, F.E., 1984. Effects of tidal currents on meiofauna densities in vegetated salt-marsh sediments. Mar. Ecol. Prog. Ser. 19, 49-53.

Fleeger, J.W., Yund, P.O., Sun, B., 1995. Active and passive processes associated with initial settlement and postsettlement dispersal of suspended meiobenthic copepods. J. Mar. Res. 53, 609-645.

Gallucci, F., Moens, T., Vanreusel, A., Fonseca, G., 2008. Active colonisation of disturbed sediments by deep-sea nematodes: evidence for the patch mosaic model. Mar. Ecol. Prog. Ser. 367, 173-183.

Giere, O., 2009. Meiobenthology: The Microscopic Motile Fauna of Aquatic Sediments. Springer-Verlag, Berlin (527 pp.).

Gontikaki, E., van Oevelen, D., Soetaert, K., Witte, U., 2011. Food web flows through a sub-arctic deep-sea benthic community. Prog. Oceanogr. 91, 245-259.

Gooday, A.J., 2002. Biological responses to seasonally varying fluxes of organic matter to the ocean floor: a review. J. Oceanogr. 58, 305-332.

Gray, J.S., 1967. Substrate selection by archiannelid protodrilus rubropharyngeus. Helgol. Wiss. Meeresunters. 15, 253-269.

Guilini, K., Soltwedel, T., van Oevelen, D., Vanreusel, A., 2011. Deep-sea nematodes actively colonise sediments, irrespective of the presence of a pulse of organic matter: results from an in-situ experiment. PLoS One 6.

Hagerman, G.M., Rieger, R.M., 1981. Dispersal of benthic meiofauna by wave and current action in Bogue Sound, North Carolina, USA. Mar. Ecol. 2, 245-270.

Heip, C., Vincx, M., Vranken, G., 1985. The ecology of marine nematodes. Oceanogr. Mar. Biol. 23, 399-489.

Heip, C.P., Herman, M.J., Soetaert, K., 1998. Indices of diversity and evenness. Oceanis 24, 61-87.

Higgins, R.P.T., Thiel, H., 1988. Introduction to the Study of Meiofauna. Smithsonian Institution Press (488 pp.)

Hill, M.O., 1973. Diversity and evenness - unifying notation and its consequences. Ecology 54, 427-432.

Höckelmann, C., Moens, T., Juttner, F., 2004. Odor compounds from cyanobacterial biofilms acting as attractants and repellents for free-living nematodes. Limnol. Oceanogr. 49, 1809-1819.

Holt, J.T., Thorpe, S.A., 1997. The propagation of high frequency internal waves in the Celtic Sea. Deep-Sea Res. I Oceanogr. Res. Pap. 44, 2087-2116.

Ingels, J., Van Rooij, D., Vanreusel, A., 2006. HERMES R/V Belgica 2006/13 Biology cruise report (23-29 June 2006): Gollum Channels and Whittard Canyon.

Ingels, J., Kiriakoulakis, K., Wolff, G.A., Vanreusel, A., 2009. Nematode diversity and its relation to the quantity and quality of sedimentary organic matter in the deep Nazare Canyon, Western Iberian Margin. Deep-Sea Res. I Oceanogr. Res. Pap. 56, 1521-1539.

Ingels, J., Van den Driessche, P., De Mesel, I., Vanhove, S., Moens, T., Vanreusel, A., 2010. Preferred use of bacteria over phytoplankton by deep-sea nematodes in polar regions. Mar. Ecol. Prog. Ser. 406, 121-133.

Ingels, J. Billett, D.S.M. Vanreusel, A. 2011a. An insight into the feeding ecology of deepsea canyon nematodes - Results from field observations and the first in-situ ${ }^{13} \mathrm{C}$ feeding experiment in the Nazaré Canyon. J. Exp. Mar. Biol. Ecol. 396, 185-193.

Ingels, J., Tchesunov, A.V., Vanreusel, A., 2011b. Meiofauna in the Gollum Channels and the Whittard Canyon, Celtic Margin-How local environmental conditions shape nematode structure and function. PLoS One 6.

Jensen, P., 1981. Phyto-chemical sensitivity and swimming behavior of the free-living marine nematode Chromadorita tenuis. Mar. Ecol. Prog. Ser. 4, 203-206.

Jensen, P., 1982. Diatom-feeding behaviour of the free-living marine nematode Chromadorita tenuis. Nematologica 28, 71-76.

Jensen, P., 1987. Feeding ecology of free-living aquatic nematodes. Mar. Ecol. Prog. Ser. 35, 187-196.

Kiriakoulakis, K., Blackbird, S., Ingels, J., Vanreusel, A., Wolff, G.A., 2011. Organic geochemistry of submarine canyons: the Portuguese Margin. Deep-Sea Res. II 58, 2477-2488.

Lambshead, P.J.D., Tietjen, J., Glover, A., Ferrero, T., Thistle, D., Gooday, A.J., 2001. The impact of large-scale natural physical disturbance on the diversity of deep-sea North Atlantic nematodes. Mar. Ecol. Prog. Ser. 214, 121-126.

Lee, J.J., Tietjen, J.H., Mastropaolo, C., Rubin, H., 1977. Food quality and the heterogeneous spatial distribution of meiofauna. Helgol. Meeresunters. 30, 272-282.

McClain, C.R., Barry, J.P., 2010. Habitat heterogeneity, disturbance, and productivity work in concert to regulate biodiversity in deep submarine canyons. Ecology 91 964-976.
Moens, T., Vincx, M., 1997. Observations on the feeding ecology of estuarine nematodes. J. Mar. Biol. Assoc. U. K. 77, 211-227.

Moens, T., Vincx, M., 1998. On the cultivation of free-living marine and estuarine nematodes. Helgol. Meeresunters. 52, 115-139.

Moens, T., Van Gansbeke, D., Vincx, M., 1999a. Linking estuarine nematodes to their suspected food. A case study from the Westerschelde Estuary (south-west Netherlands). J. Mar. Biol. Assoc. U. K. 79, 1017-1027.

Moens, T., Verbeeck, L., de Maeyer, A., Swings, J., Vincx, M., 1999b. Selective attraction of marine bacterivorous nematodes to their bacterial food. Mar. Ecol. Prog. Ser. $176,165-178$.

Musat, N., Giere, O., Gieseke, A., Thiermann, F., Amann, R., Dubilier, N., 2007. Molecula and morphological characterization of the association between bacterial endosymbionts and the marine nematode Astomonema sp from the Bahamas. Environ. Microbiol. 9, 1345-1353.

Neira, C., Sellanes, J. Levin, L.A., Arntz, W.E. 2001. Meiofaunal distributions on the Per margin: relationship to oxygen and organic matter availability. Deep-Sea Res. Oceanogr. Res. Pap. 48, 2453-2472.

Ott, J., Bright, M., Bulgheresi, S., 2004. Symbioses between marine nematodes and sulfur-oxidizing chemoautotrophic bacteria. Symbiosis 36, 103-126.

Palmer, M.A., 1983. The role of behaviour and flow in the dispersal of marine meiofauna. PhD dissertation. University of South Carolina, Columbia.

Palmer, M.A., 1988. Dispersal of marine meiofauna: a review and conceptual mode explaining passive transport and active emergence with implications for recruitment. Mar. Ecol. Prog. Ser. 48, 81-91.

Palmer, M.A., Brandt, R.R., 1981. Tidal variation in sediment densities of marine benthic copepods. Mar. Ecol. Prog. Ser. 4, 207-212.

Ramirez-Llodra, E., Brandt, A., Danovaro, R., De Mol, B., Escobar, E., German, C.R., Levin, L.A., Arbizu, P.M., Menot, L., Buhl-Mortensen, P., Narayanaswamy, B.E., Smith, C.R. Tittensor, D.P., Tyler, P.A., Vanreusel, A., Vecchione, M., 2010. Deep, diverse and definitely different: unique attributes of the world's largest ecosystem. Biogeosciences 7, 2851-2899.

Rowe, G.T., Deming, J.W., 2011. An alternative view of the role of heterotrophic microbes in the cycling of organic matter in deep-sea sediments. Mar. Biol. Res. 7 , 629-636.

Schratzberger, M., Whomersley, P., Warr, K., Bolam, S.G., Rees, H.L., 2004. Colonisation of various types of sediment by estuarine nematodes via lateral infaunal migration: a laboratory study. Mar. Biol. 145, 69-78.

Schratzberger, M., Maxwell, T.A.D., Warr, K., Ellis, J.R., Rogers, S.I., 2008. Spatial variability of infaunal nematode and polychaete assemblages in two muddy subtidal habitats. Mar. Biol. 153, 621-642.

Service, S.K., Bell, S.S., 1987. Density-influenced active dispersal of harpacticoid copepods. J. Exp. Mar. Biol. Ecol. 114, 49-62.

Sherman, K.M. Coull, B.C., 1980. The response of meiofauna to sediment disturbance J. Exp. Mar. Biol. Ecol. 46, 59-71.

Tchesunov, A., Ingels, J., Popova, E.V., 2012. Marine free-living nematodes associated with symbiotic bacteria in deep-sea canyons of north-east Atlantic Ocean. J. Mar. Biol. Assoc. U. K. 15.

Thistle, D., 1988. A temporal difference in harpacticoid-copepod abundance at a deep-sea site: caused by benthic storms? Deep-Sea Res. I Oceanogr. Res. Pap. 35, 1015-1020.

Tyler, P.A., Amaro, T. Arzola, R. Cunha, M.R. de Stigter, H., Gooday, A.J., Huvenne, V. Ingels, J., Kiriakoulakis, K., Lastras, G., Masson, D., Oliveira, A., Pattenden, A Vanreusel, A., van Weering, T.C.E., Vitorino, J., Witte, U., Wolff, G.A., 2009. Europe's Grand Canyon Nazare submarine canyon. Oceanography 22, 46-57.

Ullberg, J., Olafsson, E., 2003. Free-living marine nematodes actively choose habitat when descending from the water column. Mar. Ecol. Prog. Ser. 260, 141-149.

Ulses, C., Estournel, C., de Madron, X.D., Palanques, A., 2008. Suspended sediment transport in the Gulf of Lions (NW Mediterranean): impact of extreme storms and floods. Cont. Shelf Res. 28, 2048-2070.

Van Rooij, D.D.M., Lies, L., Ingels, Jeroen, Versteeg, Willem, Ruggeberg, Andres, Jauniaux, Thierry, 2010. Cruise Report Belgica 10/17b "Belgica BiSCOSYSTEMS Il, Leg 2", "Whittard Canyon", p. 39.

Vanreusel, A., Fonseca, G., Danovaro, R., da Silva, M.C., Esteves, A.M., Ferrero, T., Gad, G. Galtsova, V., Gambi, C., Genevois, V.D., Ingels, J., Ingole, B., Lampadariou, N., Merckx B., Miljutin, D., Miljutina, M., Muthumbi, A., Netto, S., Portnova, D., Radziejewska, T. Raes, M., Tchesunov, A., Vanaverbeke, J., Van Gaever, S., Venekey, V., Bezerra, T.N. Flint, H., Copley, J., Pape, E., Zeppilli, D., Martinez, P.A., Galeron, J., 2010a. The contribution of deep-sea macrohabitat heterogeneity to global nematode diversity. Mar. Ecol. Evol. Perspect. 31, 6-20.

Vanreusel, A., De Groote, A., Gollner, S., Bright, M., 2010b. Ecology and biogeography of free-living nematodes associated with chemosynthetic environments in the deep sea: a review. PLoS One 5 .

Warwick, R.M., Platt, H.M., Somerfield, P.J., 1998. Free-living marine nematodes part III Monhysterids. Pictorial key to world genera and notes for the identification of British species. The Linnean Society of London, London (296 pp.).

Wieser, W., 1953. Beziehungen zwischen Mundhöhlengestalt, Ernährungsweise und Vorkommen bei freilebenden marinen Nematoden. Ark. Zool. 4, 439-484.

Woodgate, R.A., Fahrbach, E., 1999. Benthic storms in the Greenland sea. Deep-Sea Res. I Oceanogr. Res. Pap. 46, 2109-2127.

Yamada, K., Hirotsu, T., Matsuki, M., Butcher, R.A., Tomioka, M., Ishihara, T., Clardy, J. Kunitomo, H., Iino, Y., 2010. Olfactory plasticity is regulated by pheromonal signaling in Caenorhabditis elegans. Science 329, 1647-1650.

Zeppilli, D., Vanreusel, A., Danovaro, R., 2011. Cosmopolitanism and biogeography of the genus Manganonema (Nematoda: Monhysterida) in the Deep Sea. Animals 1 291-305.

Zimmer, R.K., Butman, C.A., 2000. Chemical signaling processes in the marine environment. Biol. Bull. 198, 168-187. 